\title{
MOVING FROM INTEGRATION TO PARTICIPATION? NOTES ON THE INTERRELATIONSHIP BETWEEN COMMUNAL AND ASSOCIATIVE RELATIONSHIPS
}

\author{
Thomas Faist ${ }^{1}$ and Christian Ulbricht ${ }^{2}$ \\ Bielefeld University
}

\begin{abstract}
There are current trends in public and academic debates which point toward a wish of some analysts and observers to "de-culturalize" debates on international migration. In German debates, it is the term "integration" which has an alleged culturalizing effect and which therefore should be avoided and discarded as a concept of practice and as a concept of theory. In contrast to these positions we argue that there is a fundamental nexus between communal relations (Vergemeinschaftung or integration) and sociation (Vergesellschaftung). It is only by relating communal relations and sociation that we can understand the logics of important institutions such as citizenship and welfare states. Analytical concepts such as Vergemeinschaftung and Vergesellschaftung are necessary because they help us to account for fundamental changes. We find that in recent decades the meaning of integration connected to nationhood in public debates has changed from an ethno-cultural understanding to a republican one which is simultaneously characterized by increasing demands upon individuals who are conceptualized as autonomous persons (individualization).
\end{abstract}

\footnotetext{
${ }^{1}$ Thomas Faist is Professor for Sociology at the Faculty of Sociology at Bielefeld University.

${ }^{2}$ Christian Ulbricht is a scientific assistant at the Faculty of Sociology at Bielefeld University.
} 


\section{Introduction}

In this article we argue that the incorporation of immigrants into nation states depends on a complex interrelationship between communal and associative relationships. Using the example of citizenship reform in Germany, we demonstrate that incorporation can never be sufficiently understood without referring to the question of belonging. In Germany it has become fashionable in recent times to reject the term "integration" in favour of "participation." The initiative "Demokratie statt Integration" 3 [Democracy not Integration], is but one example within the framework of a "post-migration society." But substituting one term in favour of another is shortsighted as well as detrimental to academic and socio-political discussion. While it may be justified as a discourse strategy of "critical intervention" (Laclau 2005), it is important to keep in mind that "integration" highlights certain aspects of social reality that "participation" does not. "Integration" refers to communal relationships (Vergemeinschaftung), underpinned by characteristic feelings of belongingness and by the setting of boundaries, and includes the binary conceptualization of people as either in-group members or outsiders. "Participation" has more to do with associative relationships (Vergesellschaftung), for example, in the instrumental consideration of utility by means of contracts in markets; common interests expressed by organisations; or in exercising civil, political, social and cultural rights and responsibilities. ${ }^{4}$ In this respect, the participation discourse addresses contractual, legal and interest-based types of involvement that are viewed as particularly desirable in order to be part of society.

Nowadays, one might be inclined to notice an inversion in the polarity of community and society. After all, the ideal typical construction as envisaged by Ferdinand Tönnies ${ }^{5}$ continues to have considerable traction in current academic and public discussion. Classical social theorists were wary of the spread of "society" and deeply lamented the loss of "community." This process was designated by key terms such as alienation (Marx), anomie (Durkheim), mass society (Simmel) and disenchantment (Weber). Taking a closer look at today's academic participation debates, the impression arises that few contributors lament the dissolution of community in the form of large political collectives such as nations; however, there is a greater attachment to communities based on family and faith ties. The nation and its implied exclusive belonging is no longer considered current for a large number of observers. Yet those observers who nevertheless choose to position themselves within the "iron-cage of belonging" (Nassehi 1997), will inevitably be confronted with significant consequences relevant to inequality. Empirical studies have confirmed that negative attributions based on ethnicity have a considerable socio-cultural impact, for instance discrimination in access to the labour market (Diehl, Friedrich and Hall 2009; Seibert HupkaBrunner, and Imdorf 2009). It is understandable, therefore, that contributors to the debate attempt to conceptualize the "boundaries of community" (Plessner 2002).

\footnotetext{
${ }^{3}$ Kritnet - Network for Critical Migration and Border Regime Research (2011). Democracy not Integration. http://www.demokratie-statt-integration.kritnet.org/demokratie-statt-integration_en.pdf

${ }^{4}$ Max Weber conceptualizes a social relationship as associative, "if and insofar as the orientation of social action within it rests on a rationally motivated adjustment of interests or a similarly motivated agreement, whether the basis of rational judgment be absolute values or reasons of expediency" (Weber, Economy and Society 1978, p. 40-41). He defines a social relationship as communal, "if and so far as the orientation of social action - whether in the individual case, on the average, or in the pure type - is based on a subjective feeling of the parties, whether affectual or traditional, that they belong together" (Weber, Economy and Society 1978, p. 40)

${ }^{5}$ Ferdinand Tönnies (1855-1936) was a co-founder of the German Society of Sociology and established the theoretical distinction between community and society.
} 
This context increases the risk that such a dualistic conception of participation and integration, or community and society, will creep into academic debates but with reversed polarity. Essential concepts of classical social thought provide the foundation for a framework for capturing new social developments, explaining existing relations and mapping out potential scopes for enquiry. In the following analysis, we approach the current debate with a theoretical lens that accounts for the changing understanding of integration. Against this backdrop it becomes obvious why the wish to "move from integration to participation" is nowadays so prominent. Such a move offers a clear direction for future research in German migration studies that goes beyond creating linkages to established positions in the sociology of citizenship (Bloemraad, Korteweg and Yurdakul 2008). We doubt that it is possible to capture current developments in the context of migration simply by substituting one term for another or creating new terms. To do so would be to neglect the interrelationship between community and society, glossing over one important question in particular: how do processes of forming community relationships affect the conditions and opportunities for participation, (i.e., associative relationships)? It has become clearer than ever that an answer to this question is needed. Indeed, empirical phenomena such as the dualism of migration vs. mobility are forcing the issue (Faist 2013). The discourse about the demographically desirable migration of highly qualified individuals (Eder, Rauer and Schmidtke 2004) seems to have had no influence on the multitude of reports claiming that migration poses a threat to German cultural and national identity. This begs the question of why qualified people are almost exclusively regarded as highly mobile people contributing to the economy, yet the idea of the migrant worker is framed in the logic of integration into a national society.

Observations like these raise further questions: which of the boundaries resulting from community formation lead to a distinction between mobile workers vs. migrant workers? What implications does this distinction have for migrants' access to their rights to citizenship, jobs, and social participation in general? This line of enquiry fundamentally and specifically addresses problems such as the ways in which nation states are currently framing their selection of migrants through legitimated discourse and how belongingness is negotiated in public spaces (Brubaker 1995; Joppke 2005; Tebble 2006; Adamson, Triadafilopoulos and Zolberg 2011). It is not possible to do these developments justice by focusing on either participation or the ethnicizing and culturalizing perspective of the integration paradigm.

Sociologically informed critical analysis ought to address two fundamental questions throughout. The first, regarding associative relationships, is how participation in society is possible. The second, regarding communal relationships, is what holds specific groups together and what effects does their boundary formation have on participation and, consequently, inequality. Both questions address the problem of how social order can be perceived; the possible ascriptions and perceptions of belongingness and participation are mutually interdependent. Furthermore, the processes underlying the formation of communal relationships are important for participation.

In general, any critical examination of the dominating concept of integration in academia, society and politics must begin with an analytical separation of the dimensions of associative relationships and communal relationships. This separation makes it possible to identify processes of boundary formation as well as general processes of social closure, particularly in the context of migration. Only then does it become possible to sufficiently conceptualize and do justice to the fundamentally important interaction between these two dimensions. After all, participation requires a socio-moral basis in order to provide resources through state regulation or 
redistribution (Walzer 2006; Kaufmann 2009). Furthermore, theories of democracy imply that solidarity amongst citizens has been and continues to be a necessary precondition for a functional political community (Offe and Preuss 1991). This raises the question of how political community constitutes itself in present circumstances. In this regard, one should not underestimate the importance of norms and values, even in a highly individualized society disintegrating into subsystems.

In the first part of our analysis, we discuss the meaning of the concept of integration within the academic sociological debate (concept of analysis). We also examine the critique of the concept in political practice (concept of practice). For both, we look at the post-migration critique and the attempts to involve processes of communal relationship formation. These are discussed with reference to systems theory and contemporary theories of integration. Our preliminary conclusion is that none of these approaches does justice to the fundamental issue of how communal relationships and associative relationships mutually influence each other, and particularly how communal relationships act as a precondition for associative relationships.

In the second part of our analysis, we argue that it is important to re-establish the relationship between belongingness and participation, that is, associative and communal relationships. Using the concept of citizenship, we illustrate how perceptions and interpretations of belongingness (communal relationships) and participation (associative relationships) work to construct membership. Belongingness in political practice is especially linked with processes of culturalization which should be analysed against the backdrop of the nexus between heterogeneity and inequality. We conclude by recommending that the analysis of communal and associative relationships be extrapolated beyond the borders of the nation state. A dichotomous conception of "inside" and "outside" will not be able to rise to this challenge.

\section{Integration and its Critics}

After more than 40 years of migration debates on the legal and social status of immigrants in Germany, numerous studies on the representation of immigrants in the public realm conclude that immigrants are frequently portrayed as a burden on society (Müller 2015). The representation of immigrants in the mass media is disproportionately negative and symbolically excluding (Eder, Rauer and Schmidtke 2004). Today, migration to Germany is increasingly discussed in terms of security. Islam is often portrayed as a major threat to the liberal democratic order. In public discourse the boundaries between immigrants and the host society are then drawn in debates on issues like Islam and gender, such as the headscarf or honour killings (Korteweg and Yurdakul 2009). As we have indicated above, one way to cope with such negative ethnicization of migration is to "de-culturalize" the integration debates, that is, to get past the perception of immigrants through an ethnic lens. Such efforts are put forward by actors who favour a post-migration-society.

The aim of post-migration critique is to establish a new ordering of knowledge within German migration research under the heading of "autonomy of migration." Autonomy of migration is conceptualized as a research approach "which examines migration-specific fields and forms of conflict" (Karakayali 2008, 258). This critique incorporates, amongst other things, the "liberal paradox" (Hollifield 1992), which contrasts the openness of national borders in the economic 
sense with the closure of national borders in the political sense. Furthermore, the conception of an autonomous field of migration, which transverses the logics of the state and the economy, addresses another important core research question. How can a social order be negotiated outside the framework of the nation state and world societal norms (Amelina 2013). In this case, the category used to analyse social order is given by an element of post-migration society known as hybrid identity (Foroutan 2013). This diffuse concept aims to deconstruct an essentialist understanding of culture. However, post-migration critique neither contributes to the question of the opening and closing of nation states, nor does it revive the flagging discussion of hybridness. To answer the former, there would have to be new insights into the functional logic of boundary formation by nation states; to answer the latter, it must be established to what extent postmigration critique reaches beyond truly innovative concepts such as "translation" as put forth by Salman Rushdie (Rushdie 1995).

One promising aspect of post-migration critique is that it seamlessly links with post-colonial perspectives that aim to venture beyond Eurocentric knowledge systems. Methodologically, both classical migration research and the transnational approach are based on the conception of space as a container. ${ }^{6}$ In this respect, these approaches can be characterized by a "methodological nationalism," which conceptually excludes identities that transcend national boundaries. Along similar lines, it has been posited that an "imperative to integrate" dominates German migration research (Transit Migration Forschungsgruppe 2007, 8). These positions reflect an overwhelming focus on identities that, interestingly, overshadow heterogeneities, such as class, and fit neatly into left-wing paradigms of multiculturalism with an anti-racist political stance. It has not yet been made clear how to conceptualize the cultural process whereby migrants themselves make sense of their situation. In this case, stabilizing the contingent character of culture is delegated to the level of the individual, who is in turn shaped by given cultures. Through categorization along a continuum of hybridity we can find out where an individual might be embedded into different contexts but not, however, how and when the potential for taking action is mobilized. Even with terms such as "new Germans" (Bota, Khuê and Özlem 2013), this perspective does not appear sufficiently distanced from methodological nationalism. Hence, statements like the following assume the role of unexamined postulates: "We are part of this society. We are different. Therefore, our differences are also a part of this German society" (Bota, Khuê and Özlem 2013, $155)$.

Such a concept of hybrid identity in post-migration society unequivocally abandons the notion that the whole individual is accepted into the host culture. It thus represents a further development over previous approaches, building on a historical perspective and arguing from a vantage point based on normative values. Recalling debates on integration/disintegration as well as on inclusion/exclusion from the mid-1990s (Heitmeyer 1997; Friedrichs and Jagodzinski 1999), it becomes apparent that the concept of post-migration society should not be targeted with the same criticism as Wilhelm Heitmeyer's disintegration theory:

\footnotetext{
${ }^{6}$ The extent to which this criticism can be applied to the transnational research perspective remains to be seen. After all, this approach popularized the concept of "methodological nationalism" in the 1990s (summarized in Wimmer and Glick-Schiller 2003) and the construct continues to be investigated predominantly from a transnational perspective (Amelina and Faist 2012).
} 
Disintegration, in this sense, is not a pathological deviation from a successful process of forming associative relationships, rather, the result of inclusion relations that themselves are to be viewed as a reaction to the reconfiguration of primary societal differentiation(Nassehi 1997, 190).

In other words, disintegration is a default condition, and, in the light of contingent opportunities for communication, it is integration that requires explanation. From the communication theory perspective of a functionally differentiated society, exclusion can practically be seen as a precondition for the inclusion of individuals. The functionally differentiated society expels individuals from society, only to partially re-include them in the logic of subsystems. People are included into the social system insofar as they are communicatively addressed by relevant overarching differentiators (for example, paying into/not paying into the economic system); they are excluded when the discrepancy between information and communication renders them invisible. The implication is that individuals are no longer required to subjugate themselves to one single entity, such as a binding and normative set of values as outlined by Emile Durkheim (1997) and Talcott Parsons (1991), for example. Indeed, from this point of view, morals are a necessary vehicle for integration but only for archaic and pre-modern societies. This "old European" idea becomes obsolete when considering equivalent functional systems whose unity originates exclusively from the differences between them.

While proponents of the post-migration perspective do not state this explicitly, their approach can be interpreted as attempting to take seriously the (theoretical) consequences of a functionally differentiated society. It is the demand derived from the postulate underpinning modern society that anyone who participates in a society should be guaranteed access to all of its functions (Bohn 2008). The concept of hybrid identity makes reference to a tendency not to address difference and foreignness in an attempt to overcome them. Attributes that are not related to function are irrelevant to accessing functional systems, for instance ethnicity, race or gender, and require further explanation. This outlook in particular informs sociological research, and prompts us to investigate the question of "which societal mechanisms lead to the differentiation of populations in modern societies divorced along ethnic-culture lines and why is there room in our society for these supposedly pre-modern types of collective communal relationships, which stand in opposition to structural individualism" (Nassehi 1997, 190).

In its understanding that the whole individual is not being integrated into society, post-migration critique appears to be very up to date. Post-migration critique has come close to the insights gained by system theoretical differentiation theories. The question then arises whether the critique has the capacity to follow the terminology of these system theoretical differentiation theories while based simultaneously on the normative conviction that a sound understanding of social inequality can help in transforming it. This question leads us into contested territory. Instead of trying to do away with social inequality, system theoretical differentiation theory aims to describe societal processes of differentiation using the terms inclusion/exclusion.

Attempts to reconcile theories of social inequality with system theoretical differentiation theories in order to identify and overcome deficits are rare. An exception is Luhmann's questioning of the primacy of functional differentiation and the replacing of it with the overarching categories of inclusion and exclusion (Luhmann 1996). The validity of the codes associated with the functional systems is becoming increasingly dependent on location (Schroer 2010, 300), with the result that the dimension of space (in a social sense) gains importance as a category. However, 
the terms inclusion/exclusion are not very helpful in understanding how access to social space is organized; they signify only that one may find oneself inside or outside.

It is universally acknowledged that space is foregrounded conceptually when discussing resources that are bound to particular social spaces. The most important socio-geographical space is without doubt the modern nation state. Drawing on a variety of theoretical traditions, we know that the nation state is both a symbolic community that encompasses subjective feelings of commonality and a legal-political community based on citizenship (among others: Anderson 1983; Calhoun 1993; Peters 1993; Gellner 2008).

Proponents of systems theory acknowledge these conditions by emphasizing that the communicative perspective is rooted just as deeply in norms and semantics as the use of function-specific binary coding (Stichweh 2009). By formulating this point of view, Stichweh takes this argument even further than Michael Bommes, who "merely" emphasizes the role of the political functional system. In order to foster loyalty, the political system includes individuals as a whole and categorizes them unambiguously according to one nation state. When accessing national resources, for instance, the welfare state, belonging to one nation state rather than another can constitute a "threshold of inequality" (Bommes 1999, 147). This idea can be expressed more pointedly by asserting that for liberal-democratic nation states a valid passport is the entry ticket to the functionally differentiated society.

This claim addresses only one side of the coin, disregarding the idea that associative relationships are fundamentally dependent on communal relationships within nation states, for instance the conception of a national identity. Stichweh's systems theory does not, however, answer the question of how such semantics and norms affect inclusion and exclusion. Richard Münch, with reference to Hondrich and Koch-Arzberger (Hondrich and Koch-Arzberger 1992), already faulted the systems perspective on integration theory for failing to address ethnicity, nationality and nationalism (Münch 1995, 65). Thus on the question of inclusion and exclusion in modern societies we are "not further, just later" ("nicht weiter, sondern nur später") (Nietzsche).

Using the concept of autonomy of migration, "critical migration research" proposes a methodological focus on the possibilities for action available to migration actors and institutions. For this purpose, critical migration research invokes Foucault's concept of governmentality. Particular emphasis is placed on the way in which numerous institutions aim to make mobility governable, whereby mobility is foremost understood as mobility of work, and the integration of migrants through categorization, for instance by territorializing the nation state. ${ }^{7}$ Critical migration scholars argue that migration research which draws on classical integration theory supports an intellectual framework that maintains discriminatory patterns against migrants. However, critical migration research falls short in at least two ways. First, by disjointedly drawing on Foucault's concept of governmentality, critical migration research loses sight of the manifold countervailing power formations on the part of migrants, particularly against state institutions. In this sense, the autonomy of migration is understood as a governmental perspective rather than the independence of migrants. Yet this is inadequate, because migrants, even irregular or illegal migrants, can be highly self-sufficient, resistant and autonomous agents

\footnotetext{
${ }^{7}$ See in particular Hess and Karakayali in "Transit Migration Forschungsgruppe 2007".
} 
vis-à-vis border and integration regimes. ${ }^{8}$ Second, conducting a sort of intellectual exorcism is not really helpful. While the critique of "integration" in the interest of problematizing a dominant knowledge system is understandable, abolishing the term does not solve the issues and questions associated with it. In this context, we assume that the term "integration" primarily refers to processes of communal relationship formation within academic and partially within political debate.

Surprisingly, integration and its critics are united by the implicit assumption that society can be conceptualized as a unified, if not relatively homogenous body. Critics of multiculturalism and post-migration and post-colonial theorists alike share this assumption. Prominent political figures such as David Cameron, Nicolas Sarkozy and Angela Merkel have been some of the most vocal critics of multiculturalism in recent years. At the Deutschlandtag (party conference) of the Junge Union (Young Conservatives) in 2010, Angela Merkel succinctly stated: "The multicultural approach has failed, it has failed completely!" The essence of the post-migration critique comes across in the following assertion:

We live in an immigrant society. This means that we need to stop talking about integration when we address the social relations that govern how we live together. Integration means that people who work, have children, grow old and die in this country have a code of conduct forced upon them before they are even part of society on equal terms. Democracy is not a golf club. Democracy means that all people have the right to figure out together and for themselves how they wish to live together. The notion of integration is an enemy to democracy"(Netzwerk Kritische Migrationsforschung). ${ }^{9}$

While these (on the surface) very disparate critiques of the practice of integration implicitly celebrate homogeneity, other voices do not even attempt a differentiated engagement with integration. The Expert Council on Migration, for instance, merges the terms integration and participation by talking about "... integration as an empirical measure of participation in central aspects of social life" (Sachverständigenrat Migration 2012, 17). At this point, we provisionally establish that the image of homogeneity explicitly formulated in public critiques of multiculturalism and, interestingly, implied in post-migration research is outdated, not least because of the increased diversification of migration and society.

Post-migration and post-colonial critiques are apparently unaware of the evolution of classical theories of integration over the past decades, in which there has been a movement away from an emphasis on cultural homogeneity. It has been a long journey from the classical assimilation theories as formulated by the Chicago School ${ }^{10}$ to multiculturalism, to newer assimilation theories and ending with concepts of diversity. All of these theories and perspectives focus attention on the connection between associative and communal relationships. The adaptation of migrants to a culturally homogenous majority society, a process that usually spans several generations, plays an important role in assimilation theories developed within the Chicago School framework up until the 1960s (Park 1928; Gordon 1964). At the crux of these theories is the incorporation or subordination of migrants into or within an existing dominant social

\footnotetext{
${ }^{8}$ See for instance Barron et al. 2011.

${ }^{9}$ Kritnet - Network for Critical Migration and Border Regime Research (2011). http://demokratie-stattintegration.kritnet.org/

${ }^{10}$ In part also earlier, see e.g. Kivisto 2005.
} 
structure or culture, even if, according to Park, processes of adaptation can move in the opposite direction. The implicit assumptions of the model are obvious: the integration of migrants is more or less a unilinear process of adaptation to the host society. Newer theories of assimilation question the existence of a fixed cultural core of the majority society and shift the focus to processes of boundary formation between migrants and members of majority social groups (Alba and Nee 2003). Assimilation or integration exists when boundaries disintegrate, when minority group members overstep boundaries or when new minorities face exclusion in the sense of sociocultural closure. Contemporary theories of assimilation thus reflect a strong turn toward social constructivism.

The political theory of multiculturalism remains far removed from these social constructivist contributions. Essentially, multiculturalism is a normative strain of theory influenced by the discussions of the rights of national minorities in the 1980s and 1990s and applied as well to immigrant minorities. A central assumption and one of the most significant demands of multiculturalism as a social theory and political practice is that only the recognition of all cultures as equally valid can create a solid foundation for effective social participation (Kymlicka 1995). Multiculturalism proposes the validation of cultural practices in minority groups as a precondition for participation in all functional systems and social fields. Yet critics of multiculturalism frequently assert that validating minority cultures encourages the suppression of dissidence within these groups; with regard to national minorities, Québec is often cited as an example (Barry 1991).

When comparing different conceptions of integration it becomes apparent that communal and associative relationships are usually the focus of analysis. Older theories of assimilation, for example, postulate the acculturation of migrants in regard to language and work ethic as a precondition for participation in social fields such as school, work and politics. Concepts of diversity also indulge in a kind of methodological holism, even if, unlike in multiculturalism, this breaks down collectives into individuals as carriers of cultural competences. Newer theories of assimilation emphasize the social constitution of boundaries between majority and minority groups. In doing so they pay tribute to older social constructivist and social anthropologist traditions (Barth 1969), which have recently been revived (Wimmer 2008). The social mechanisms behind the transformation of culturally coded differences (heterogeneity) into inequalities have been neglected in past analyses.

\section{The Climbing Team of Communal and Associative Relationships - Explored through the Example of Citizenship}

The debate on the reform of citizenship laws that has been taking place in Germany since the 1990s, shows how important it is to examine the interplay between communal and associative relationships and to clarify which theoretical or socio-political outcomes are present. Citizenship as the idea and practice of full membership in a unified political body on the basis of equal legal status is an ideal concept for this purpose. Equal democratic participation based on affiliations with imaginary, and in the sense of the Thomas theorem also real, communities may be hindered by a variety of inequalities originating from processes associated with civil society, the market and the family. At the same time, the outward social closure associated with citizenship in nation 
states constitutes a moment in which inequality is generated. For example, the interplay of communal and associative relationships can be illustrated by the functional logic of the welfare state constituted within a nation state. This interaction can also be observed in the political conflicts surrounding citizenship reforms in the Federal Republic of Germany since the late 1990s.

Hailed by its proponents of as an act of modernization, the German citizenship law reform of 2000 may constitute a success story within the aforementioned narrative. The reform introduced limited jus soli rights, which attribute citizenship and citizenship rights on the basis of the country-of-birth principle (Faist 2007). According to the law, children born in Germany to foreign nationals who have lived in the country for at least eight years are (also) German citizens. ${ }^{11}$ The citizenship law reform in 1999 of the Social Democrats (SPD) and the Green Party (Bündnis 90/Die Grünen) coalition augmented the "right of blood" (jus sanguinis) model of citizenship. This had been the primary means of acquiring German citizenship, with provisions for "right of soil" (jus soli) citizenship, which are in comparison to other European countries very wide-reaching. Additionally, the required duration of residence for obtaining citizenship was shortened to eight years. Dual nationality was not expected to become the normal case, but provisions were made for a number of exceptions. Children between the ages of 18 and 23 born to foreign nationals in Germany were required by the reform to choose between German nationality and that of their parents. This had become known as the Optionspflicht (duty to decide), which was recently abolished (Winter et al. 2015).

Proponents of jus soli and dual nationality base their central arguments for simplifying the process of citizenship acquisition on different variants of creating political and social equality by means of associative relationships on the basis of legal equality. The Social Democrats (SPD), the Green Party (Bündnis 90/Die Grünen), the Party of Democratic Socialism (PDS) and some in the Liberal Party (FDP) had two perspectives on political inclusion on the basis of attaining citizenship. On the one hand, they saw it as a precondition for successful integration. On the other hand, they also saw this type of political inclusion as a question of equal rights and the creation of legal as well as social equality. The specific arguments for equality were related to various points of comparison. For instance, it was argued that just like German citizens, immigrants also have a legitimate claim, on the basis of attaining citizenship, to the same scope of civil, social and especially political rights in the host country. Making immigrants equal by means of citizenship rights was also said to have the suspected effect of combating racist attitudes by removing the institutional basis for discriminating between foreigners and Germans. In sum, citizenship confers rights of access and therefore equal access to equal life chances.

Furthermore, it was postulated that attaining citizenship fosters feelings of equal belongingness among immigrants as well as identification with German society. The attainment of citizenship was also often viewed as a necessary way of balancing the rights and responsibilities of immigrants, sometimes inviting references to the slogan of the American Revolutionary War "no

\footnotetext{
${ }^{11}$ However, this narrative only takes one component of migration and integration into consideration - namely those individuals who settle down as permanent residents. What happens to those who stay for shorter periods of time, be they students, workers on fixed-term contracts, seasonal workers, individuals with mobile lifestyles or expatriates such as managers and diplomats? Temporary residence is not a new phenomenon, even though mass media often cultivates the image that we have only recently entered an age of migration.
} 
taxation without representation." This slogan implies that those who have been fulfilling their responsibilities by paying their taxes and their social insurance contributions are legitimately entitled to the full scope of the corresponding rights. With respect to the fundamental entitlement to German citizenship of repatriated ethnic Germans who had settled in Eastern Europe, it was deemed necessary to establish equal treatment for long-time resident migrant workers by tolerating dual nationality. This argument for equal treatment continues to play a role in the relationship between non-citizens from countries within the European Union and non-EU citizens. According to the ruling of the German Constitutional Court (Bundesverfassungsgericht) in 1989 on the right to vote for foreigners, non-EU citizens can only exercise the same municipal-level voting rights as non-German EU citizens after becoming German citizens. Arguments in favour of the debated reforms which were based on Germany's collective identity drew, to varying degrees, on the belated acknowledgement of Germany as an immigration country and on its commonly accepted pro-European stance. The idea was to reform German citizenship legislation so that the liberal developments occurring in other European states could take hold in Germany as well.

Opponents of the controversial elements of German citizenship law reform tended to identify the term "integration" with "loyalty." Whereas proponents believed that the political loyalty of immigrants results from political inclusion on the basis of equal rights, opponents viewed political loyalty as a consequence of comprehensive societal integration. According to the stance of the Conservatives (CDU/CSU), the attainment of citizenship in itself is not a means of integration; rather, citizenship should be granted once palpably successful integration has taken place. Participation in public institutions and membership in civil society groups were framed as associative relationships in this case. According to this view, the regulations governing naturalization must be based on reliable criteria indicative of a move toward successful communal relationships. These measures are intended to prevent the naturalization of individuals who have not developed a true connection with Germany and are reluctant to form one due to a desire eventually to return to their country of origin. Furthermore, accepting dual nationality, even with respect to migrants who intend to stay in Germany in the long term, is still considered by Conservatives to be detrimental to integration. They argue that this frees migrants from making the necessary independent efforts to integrate. In this narrative, integration has almost exclusively been framed as a task for the immigrants: as their individual willingness, effort and accomplishment.

With respect to democratic legitimacy, the Conservatives (CDU/CSU) defended a position held since the controversy concerning voting rights for foreigners in the early 1990s. This position predominantly emphasized the civil responsibilities that individuals must fulfil if they wish to enjoy the full scope of democratic participation. Following this logic, the acceptance of dual nationality would lead to the privileging of immigrants, who would be able to enjoy corresponding rights conferred by two different citizenships, which would be rejected by the majority of the German population.

The Conservatives (CDU/CSU) position was characterized in two ways by a "communitarian" view rather than the vestiges of unenlightened ethno-cultural ignorance. On one hand, this view is based on the sovereign right of nation states, as recognized by international law, to determine the criteria for entry to and membership in the state. On the other hand, this view emphasizes the conviction that social participation does not emerge as a result of legislation and politics alone. 
Rather, it depends on social resources such as self-organization and solidarity within the framework of what is frequently referred to as civil society. In other words, participation relates closely to aspects of communal relationships. In this sense, people who are in the process of applying for German citizenship are expected to have already developed certain civil competencies that allow them to live as self-sufficiently as possible. It is worth noting that, based on explicit assertions, there is still hardly any evidence of an intention to foster cultural assimilation in the sense of adaptation to specific practices and ways of life. Rather, the selfsufficient citizen is expected to have adequate educational as well as professional qualifications or the individual motivation and competencies to acquire them. It is also expected that this citizen will have social networks so that they will require state support only in exceptional circumstances. This understanding of the connection between associative and communal relationships corresponds to recognizable elements of traditionally conservative as well as economically liberal positions. These positions advocate narrowing the scope of state responsibility down to international and domestic security as well as delegating numerous functions of the state to the private sector and initiatives in civil society.

Finally, the divergent positions of these two political camps showcase two fundamentally different understandings of political legitimacy. For the Social Democrats (SPD), The Green Party (Bündnis 90/Die Grünen) and the Party of Democratic Socialism (PDS), democratic legitimacy was essentially a question of input: the quality of the political process is fundamentally based on the widest possible inclusion and democratic participation of those governed by its laws. The Conservatives (CDU/CSU) on the other hand obviously favoured an understanding of legitimacy that focused on the efficacy or the output of state regulation. The effectiveness of the state within the framework of its core functions appears here as the central aspect in generating political support from the state and the government. These institutions are, in turn, predominantly accountable to the autochthonous majority society.

The illustrative example of dual nationality clarifies the interplay of communal and associative relationships. The Social Democrats (SPD), The Green Party (Bündnis 90/Die Grünen) and the Party of Democratic Socialism (PDS) favoured the argument that equal rights are first necessary to equip individuals to be able to prepare themselves for the demands of a differentiated society and thereby to participate in it. The Conservatives (CDU/CSU) argued that social participation is linked to certain preconditions. In Germany, these socio-moral preconditions of citizenship are discussed using the meta-concept of integration. Depending on one's political orientation, citizenship and the rights associated with it are then conceptualized as either a precondition for integration or as the crowning moment in completing the process of integration. In the latter case, citizenship is a reward for the individual achievement of the migrant. Both positions, clearly expressed, for instance, during the Bundestag debates on dual nationality in the late 1990s, accept the discourse of equality within nation states: those who see citizenship as a means of enabling membership emphasize equality of opportunity, while those who define citizenship as the crowning moment of the integration process focus on the idea that equality first must be earned. The more diffuse the conception of social integration (the nation) is, the stronger the imperative for migrants to mobilize and integrate and the slimmer the chances of "multicultural" citizenship. Interestingly, integration generally relates only to migrant workers and refugees, while the highly qualified are not considered to be migrants at all. The latter group is not referred to through the paradigm of integration, but rather as human capital which enhances economic competition (Faist and Ulbricht 2015). Further research needs to show whether the highly 
qualified with their status as self-sufficient citizens represent the new legitimate type of communal relationships. In this regard, being individualized in a way that conforms to the market bestows belongingness to the symbolic community of Germany.

In this view, the supposedly backward traditional forms of communal relationships practiced by migrants are the cause of segregation and exclusion from social participation. This is underpinned by the assumption that less privileged migrants must be shown the basic tenets of liberal-democratic culture ${ }^{12}$ and need to be liberated from the traditional ties to their culture of origin. Again, community appears here as a characteristic of pre-modern society. The idea that aspects of communal relationships via national belonging predominantly serve the selfconfirmation of the majority society, as demonstrated in the public political discussion on the reform of citizenship law in Germany, is overlooked. This should not be taken to support the argument that communal relationships are "only" an element of symbolic politics. Rather, fundamental concepts such as those underlying socio-political interventions are affected. Educational policy constitutes a significant example in this regard. In current debates, the requirements of social participation are being expressed as follows: the preschool and school system should also be the foundation for the children of migrant workers so that they, too, have realistic opportunities in the job market (Sachverständigenrat deutscher Stiftungen für Integration und Migration 2013; Kuhnhenne et al. 2012). In the past three decades, two to three times as many young people with a "migration background" as those without have been unable to find apprenticeships. Often these young people have also not attained a school-leaving qualification (Hauptschulabschluss) and are overrepresented in schools for pupils with special educational needs. This raises the question of how young people with a "migration background" can acquire the skills they need to participate in the job market. Any measures to further this goal must be underpinned with solid financing and follow the principle of educational foresight rather than compensatory aftercare by means of social welfare programmes. Without a clear grounding in a collective "us" - especially on a national level - political coalitions that challenge the alliance of interests benefiting older generations, who currently dominate the discourse, are unthinkable. In this regard, accomplishing the task of integrating the autochthonous population into a multiethnic social reality is vital for any progress toward equality of participation for migrants and their children. However, new types of communal relationships in majority groups will not necessarily lead to conflict-free dealings with migration, even though they are appropriate to a culturally heterogeneous society and function as a socio-moral basis for increased participation.

\section{Conclusion: Inescapable Culturalization}

As we have tried to demonstrate, processes of communal relationship formation are ambivalent, function as a socio-moral basis for wide-ranging social integration on a national level (e.g., resources for the welfare state, just participation for migrants and their children), and also constitute elements of culturalization or boundary formation along cultural lines. These dual consequences, that is communal relationships as a basis for the welfare state and even democracy on the one hand and the inescapable culturalization of resource conflicts on the other, provide a

\footnotetext{
12 However, a populist version of this relationship says that in contrast with the "German" underclass, "Arabs and Turks" are not suited for this, as for example in Thilo Sarrazin's polemic book (2010).
} 
fundamental starting point for substantive analyses, particularly with respect to the question of participation of migrants and non-migrants. Consensus and conflict over resources, recognition and power cannot be sufficiently understood without referring to the question of belonging with respect to migrants and non-migrants. This speaks against frivolously discarding the term integration in favour of participation.

In this context, the "de-culturalization" of the debate on integration as aspired to by the postmigration perspective would be a dangerous illusion. Especially since boundary formation between groups promotes competition for resources, status and power, the struggle for participation opportunities remains ubiquitous. Some approaches in inequality research emphasize that the competition for scarce resources leads to the formation of boundaries between groups as a by-product of social closure, opportunity hoarding, exploitation and other mechanisms relating to inequality (Tilly 1998). The categorical inequalities produced by this process (Massey 2007) often take the form of dichotomies such as black/white, man/woman or migrant/non-migrant. As long as there is competition for valuable material and symbolic goods, processes of boundary formation follow cultural heterogeneities. We need to take into account that (cultural) differences alone do not necessarily imply social inequality or result in exclusionary processes of communal relationship formation. Examples abound: religious differences in Europe - for instance Protestantism and Catholicism as different Christian denominations - are no longer a basis for exclusion, social closure or exploitation; and in recent times religion has become a characteristic of social segregation. The latter can be observed in the behaviour of dominant population groups in Western Europe toward "Muslim" immigrants (Foner and Alba 2008).

For migrants, what is significant is not only aspects of the distribution of the relevant material resources, that is, differences and similarities between migrants and non-migrants in important life spheres, but also aspects of the perception of and consequently the boundaries between categories, such as groups. Two patterns of social segregation are particularly important here: the shifting and the blurring of boundaries. In Germany, data from the German General Social Survey ALLBUS (Allgemeine Bevölkerungsumfrage der Sozialwissenschaften) suggest that there were significant changes in the boundaries between migrant groups and the majority group ("German Germans") between 1996 and 2006. First, a boundary shift becomes apparent: the majority group has clearly acknowledged the belongingness of certain migrant groups (Italians, Spanish, Greeks). These groups are now considered to be part of the majority population. However, attitudes to some other categories have not changed and in some cases there has been an increase in (perceived) differences, for instance with respect to "Muslims." Second, the blurring of boundaries with respect to certain categories can also be observed between 1996 and 2006, for instance in the majority population's increasing support for the demand that people born in Germany should have the right to German citizenship. Alongside other factors, social class determines how members of various ethnic groups are judged. Semi-experimental studies investigating recruitment behaviour in the job market show that discrimination is considerably rarer when the subject's interaction partner is regarded as an equal in terms of social status. Socioeconomic position and command of the majority group's language are strong predictors in these scenarios (Fincke 2009).

With regard to citizenship, newer research questions the extent to which communal relationships in Western nation states have ceased to run along the boundary between ethnic versus republican 
understandings of nation (Gerdes and Faist 2006). The de-legitimization of the ethnicity argument does not necessarily cause the normative basis for citizenship in Germany to vanish, though this seems to be what the current participation discussion suggests. Rather, it can be interpreted as a sign of a change in which other integration norms come to the fore. But the question is, which ones? In a manner similar to the way in which the spirit of capitalism must adapt to the current demands of the motivational and binding forces of capitalism (Boltanski and Chiapello 2005), the normative dimension of citizenship is also subject to change. A theory or empirical model reconstructing the change in the normative basis has not yet been developed, however some theoretical work is beginning to move in that direction, for instance work on "identity liberalism" (Tebble 2006). This shows how liberal Western nation states turn democratically legitimizable integration into citizenship. The legitimate selection of immigrants thereby moves away from public, openly group-based discrimination toward an individual-based understanding of integration (Joppke 2005) with special recourse to human capital. The individual bears the full burden of and responsibility for social cohesion. A good society can be achieved through the productivity of the individual and their active willingness to integrate. The Blue Card Initiative (Soysal 2012) illustrates that this norm is predominantly represented by highly qualified immigrants. Joppke expresses this concisely: "The liberal state is only for liberal people" $(2010,140)$.

Our argument is that even within a liberal nation state that guarantees and ensures the rights and responsibilities of its citizens, associative relationships depend on the symbolic imputation of community. This type of communal relationship has indeed fundamentally changed in Germany. The debates concerning the reform of citizenship law in the year 2000 illustrate this pertinently. In these debates an ethno-cultural understanding of the nation was relinquished in favour of one that is informed by republicanism but extends the communitarianism found in republicanism with individualization demands. Neither the cultural integration debate nor the current discussion on participation are capable of capturing this type of change. 


\section{REFERENCES}

Adamson, Fiona B., Triadafilos Triadafilopoulos, and Aristide R. Zolberg. 2011. "The Limits of the Liberal State: Migration, Identity and Belonging in Europe." Journal of Ethnic and Migration Studies 37 (6): 843-59. doi:10.1080/1369183X.2011.576188.

Alba, Richard, and Victor Nee. 2003. Remaking the American Mainstream. Cambridge,MA: Harvard University Press.

Amelina, Anna. 2013. “Transnationale Inklusion Als Ein Multilokales Phänomen.” In Die Integrationsdebatte Zwischen Assimilation Und Diversität, edited by Özkan Ezli, Andreas Langenohl, Valentin Rauer, and Claudia Marion Voigtmann, 119-58. Bielefeld: Transcript.

Ammelina, Anna and Thomas Faist. 2012. De-naturalizing the national in research methodologies: Key concepts of transnational studies in migration. Ethnic and Racial Studies 35 (10): 1707-1724.

Anderson, Benedict. 1983. Imagined Communities. London/New York: Verso.

Barron, Pierre, Anne Bory, Sébastian Chauvin, and Nicolas Jounin. 2011. On Bosse Ici, on Reste Ici. Paris: La Découverte.

Barry, Brian. 1991. Liberty and Justice. Oxford: Clarendon Press.

Barth, Fredrik. 1969. Ethnic Groups and Boundaries. Oslo: Universitetsforlaget.

Bloemraad, Irene, Anna Korteweg, and Gökçe Yurdakul. 2008. "Citizenship and Immigration: Multiculturalism, Assimilation, and Challenges to the Nation-State." Annual Review of Sociology 34 (January). Annual Reviews: 153-79.

Bohn, Cornelia. 2008. "Inklusion Und Exklusion: Theorien Und Befunde .” Soziale Systeme 14 (2): 17190.

Boltanski, Luc, and Eve Chiapello. 2005. The New Spirit of Capitalism. London: Verso.

Bommes, Michael. 1999. Migration Und Nationaler Wohlfahrtsstaat. Opladen: Westdeutscher Verlag.

Bota, Alice, Pham Khuê, and Top Özlem. 2013. “"Neue Deutsche'.” In Das Neue Deutschland, edited by Özkan Ezli and Gisela Staupe, 154-56. Konstanz: Konstanz University Press

Brubaker, Rogers. 1995. "Comments on 'Modes of Immigration Politics in Liberal Democratic States'." International Migration Review 29 (4): 903-7. doi:10.2307/2547730.

Calhoun, Craig. 1993. "Nationalism and Ethnicity.” Annual Review of Sociology 19 (1): 211-39. doi:DOI: 10.1146/annurev.so.19.080193.001235.

Diehl, Claudia, Michael Friedrich, and Anja Hall. 2009. "Jugendliche Ausländischer Herkunft Beim Übergang in Die Berufsausbildung: Vom Wollen, Können Und Dürfen.” Zeitschrift Für Soziologie 38 (1): 48-67.

Durkheim, Émile. 1997 [1893]. The Division of Labor in Society. New York: Free Press. 
Eder, Klaus, Valentin Rauer, and Oliver Schmidtke. 2004. Die Einhegung Des Anderen. Wiesbaden: VS Verlag.

Faist, Thomas. 2013. “The Mobility Turn: a New Paradigm for the Social Sciences?”. Ethnic and Racial Studies 36 (11). Routledge: 1637-46. doi:10.1080/01419870.2013.812229.

Faist, Thomas, and Christian Ulbricht. 2015. "Doing National Identity Through Transnationality. Categorizations and Mechanisms of Inequality in German Integration Debates." In Fear and Anxiety over National Identity, edited by Nancy Foner and Patrick Simon, 189-212. New York: Russell Sage Foundation.

Fincke, Gunilla. 2009. Abgehängt, Chancenlos, Unwillig? Wiesbaden: VS Verlag für Sozialwissenschaften.

Foner, Nancy, and Richard Alba. 2008. "Immigrant Religion in the U.S. and Western Europe: Bridge or Barrier to Inclusion?.” International Migration Review 42 (2). Blackwell Publishing Inc: 360-92. doi:10.1111/j.1747-7379.2008.00128.x.

Friedrichs, Jürgen, and Wolfgang Jagodzinski. 1999. Soziale Integration. Opladen: Westdeutscher Verlag.

Gellner, Ernest. 2008. Nations and Nationalism. Cornell University Press.

Gerdes, Jürgen, and Thomas Faist. 2006. "Von Ethnischer Zu Republikanischer Integration.” Berliner Journal Für Soziologie 16 (3). VS Verlag für Sozialwissenschaften: 313-35. doi:10.1007/s11609006-0029-x.

Gordon, Milton. 1964. Assimilation in American Life. New York: Oxford University Press.

Heitmeyer, Wilhelm. 1997. Was Hält Die Gesellschaft Zusammen? Edited by Wilhelm Heitmeyer. Frankfurt am Main: Suhrkamp Verlag.

Hess, Sabine. 2013. “Die Beharrliche Kraft Der Migration.” In Dabeisein Und Dazugehören, edited by Heinz Ulrich Brinkmann and Haci-Halil Uslucan, 67-84. Wiesbaden: VS Verlag für Sozialwissenschaften.

Hollifield, James F.. 1992. Immigrants, Markets, and States. Harvard University Press.

Hondrich, Karl O., and Claudia Koch-Arzberger. 1992. Solidarität in Der Modernen Gesellschaft. Frankfurt a.M. : S. Fischer.

Joppke, Christian. 2005. "Exclusion in the Liberal State the Case of Immigration and Citizenship Policy." European Journal of Social Theory 8 (1). SAGE Publications: 43-61. doi:10.1177/1368431005049327.

Karakayali, Serhat. 2008. Gespenster Der Migration. Bielefeld: transcript Verlag.

Kaufmann, Franz-Xaver. 2009. Sozialpolitik Und Sozialstaat: Soziologische Analysen. Springer DE.

Kivisto, Peter. 2005. Incorporating Diversity. Boulder, CO: Paradigm Publishers. 
Korteweg, Anna, and Gökçe Yurdakul. 2009. "Islam, Gender, and Immigrant Integration: Boundary Drawing in Discourses on Honour Killing in the Netherlands and Germany." Ethnic and Racial Studies 32 (2): 218-38. doi:10.1080/01419870802065218.

Kuhnhenne, Michaela, Ingrid Miethe, Heinz Sünker, and Oliver Venzke. 2012. (K)Eine Bildung Für Alle - Deutschlands Blinder Fleck. Berlin: Budrich.

Kymlicka, Will. 1995. Multicultural Citizenship. New York: Oxford University Press.

Laclau, Ernesto. 2005. On Populist Reason. London: Verso.

Luhmann, Niklas. 1996. “Jenseits Der Barbarei.” In Modernität Und Barbarei, edited by Hans-Georg Soeffner and Max Miller, 219-30. Frankfurt a.M.: Suhrkamp

Massey, Douglas. 2007. Categorically Unequal. New York: Russell Sage Foundation.

Mau, Steffen. 2004. "Welfare Regimes and the Norms of Social Exchange.” Current Sociology 52 (1): 53-74. doi:10.1177/0011392104039314.

Müller, Daniel. 2005. “Die Darstellung Ethnischer Minderheiten in Deutschen Massenmedien.” In Massenmedien Und Die Integration Ethnischer Minderheiten in Deutschland (Band 1), edited by Rainer Geißler and Horst Pöttker, 83-126. Bielefeld: transcript.

Münch, Richard. 1995. “Elemente Einer Theorie Der Integration Moderner Gesellschaften - Eine Bestandsaufnahme." Berliner Journal Für Soziologie 1: 5-24.

Münch, Richard. 2004. Soziologische Theorie. Frankfurt am Main/ New York: Campus.

Nassehi, Armin. 1997. "Das Stahlharte Gehäuse Der Zugehörigkeit." In Nation, Ethnie, Minderheit, edited by Armin Nassehi, 177-208. Köln/Weimar/Bonn: Böhlau Verlag.

Offe, Claus, and Ulrich K Preuss. 1991. "Democratic Institutions and Moral Resources.” In Political Theory Today, edited by David Held, 143-71. Stanford, California.

Park, Robert E. 1928. "Human Migration and the Marginal Man.” American Journal of Sociology 33 (6): 881-93.

Parsons, Talcott. (1991) [1951]. The Social System, edited by Bryan S. Turner. Routledge: London

Peters, Bernhard. 1993. Die Integration Moderner Gesellschaften. Frankfurt a.M.: Suhrkamp.

Plessner, Helmuth. 2002. Grenzen Der Gemeinschaft. Frankfurt am Main: Suhrkamp.

Rauer, Valentin. 2013. "Integrationsdebatten in der deutschen Öffentlichkeit (1947-2012). Ein umstrittenes Konzept zwischen 'region building' und "nation-saving". In Die Integrationsdebatte zwischen Assimilation und Diversität. Grenzziehungen in Theorie, Kunst und Gesellschaft edited by Özkan Esli, Andreas Langenohl, Valentin Rauer, and Claudia Marion Voigtmann,, 51-86. Bielefeld: Transcript.

Rushdie, Salman. 1995. East, West. UK: Vintage Books. 
Sachverständigenrat deutscher Stiftungen für Integration und Migration. 2013. "Hürdenlauf Zur Kita." URL: http://www.svr-migration.de/content/wp-content/uploads/2013/06/SVR_FB_Kita_Web.pdf.

Schroer, Markus. 2010. "Funktionale Differenzierung Versus Soziale Ungleichheit." In Soziologische Kontroversen, edited by Georg Kneer and Stephan Moebius, 291-313. Frankfurt a.M.: Suhrkamp.

Seibert, Holger, Sandra Hupka-Brunner, and Christian Imdorf. 2009. "Wie Ausbildungssysteme Chancen Verteilen.” KZfSS Kölner Zeitschrift Für Soziologie Und Sozialpsychologie 61 (4): 595-620. doi:10.1007/s11577-009-0084-3.

Soysal, Yasemin Nuhoğlu. 2012. "Citizenship, Immigration, and the European Social Project: Rights and Obligations of Individuality.” The British Journal of Sociology 63 (1): 1-21. doi:10.1111/j.14684446.2011.01404.x.

Stichweh, Rudolf. 2009. "Leitgesichtspunkte Einer Soziologie Der Inklusion Und Exklusion.” In Inklusion Und Exklusion, edited by Rudolf Stichweh and Paul Windolf, 29-44. Wiesbaden: VS Verlag für Sozialwissenschaften.

Tebble, Adam J. 2006. “Exclusion for Democracy.” Political Theory 34 (4): 463-87. doi:10.1177/0090591706288519.

Tilly, Charles. 1998. Durable Inequality. Berkeley, CA: University of California Press.

Weber, Max. 1978 [1921]. Economy and Society, edited by Guenther Roth and Claus Wittich. Berkeley: University of California Press.

Wimmer, Andreas and Nina Glick-Schiller. 2003. "Methodological nationalism, the social sciences, and the study of migration: An Essay in historical epistemology." International Migration Review 37(3): 576-610.

Wimmer, Andreas. 2002. "Nationalist Exclusion and Ethnic Conflict: Shadows of Modernity." Cambridge, UK ; New York, NY, USA : Cambridge University Press.

Winter, Elke, Annkathrin Diehl and Anke Patzelt, "Ethnic Nation No More? Making Sense of Germany's New Stance on Dual Citizenship by Birth", Review of European and Russian Affairs (RERA), 9 (1): 1-19. https://journals.carleton.ca/rera/index.php/rera/article/view/110/160

Zolberg, Aristide R, and Long L. Woon. 1999. "Why Islam Is Like Spanish: Cultural Incorporation in Europe and the United States.” Politics \& Society 27 (1): 5-38. doi:10.1177/0032329299027001002. 
Published by the Centre for European Studies at Carleton University, Ottawa, Canada Available online at: journals.carleton.ca/rera/index.php/rera

RERA is an electronic academic peer-reviewed journal. Topics relate to the European Union, its Member States, the former Soviet Union, and Central and Eastern Europe. The journal is a joint project supported by the Canada-Europe Transatlantic Dialogue - a cross-Canada research network supported by the Social Sciences and Humanities Research Council of Canada (SSHRC) - along with the Institute of European, Russian and Eurasian Studies (Carleton University) and its associated research unit, the Centre for European Studies.

RERA aims to provide an accessible forum for research, to promote high standards of research and scholarship, and to foster communication among young scholars.

\section{Contact:}

Carleton University

The Centre for European Studies

1103 Dunton Tower

1125 Colonel By Drive

Ottawa, ON K1S 5B6

Canada

Tel: +01 613 520-2600 ext. 3117; E-mail: rera-journal@ carleton.ca

\section{Creative Commons License}

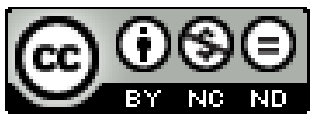

creativecommons.org/licenses/by-nc-nd/3.0

This Working Paper is licensed under a Creative Commons Attribution-Non-CommercialNo Derivs 3.0 Unported License (CC BY-NC-ND 3.0).

Articles appearing in this publication may be freely quoted and reproduced, provided the source is acknowledged. No use of this publication may be made for resale or other commercial purposes.

ISSN: 1718-4835

(C) 2017 The Author(s) 